\title{
Pengembangan bahan ajar perakitan komputer bermuatan augmented reality untuk menumbuhkan keaktifan belajar siswa
}

\author{
Binti Afifah ${ }^{1}$, Triyanna Widiyaningtyas ${ }^{2}$, Utomo Pujianto ${ }^{3}$ \\ 1. Universitas Negeri Malang, Indonesia | bafifah72@gmail.com \\ 2. Universitas Negeri Malang, Indonesia | triyannaw.ft@um.ac.id \\ 3. Universitas Negeri Malang, Indonesia | utomo.pujianto.ft@um.ac.id
}

\begin{abstract}
Abstrak
Studi ini berfokus pada pengembangan bahan ajar perakitan komputer yang bermuatan AR. Berdasarkan hasil observasi dan wawancara di SMK Negeri 1 Undanawu Blitar, diperoleh fakta bahwa beberapa siswa merasa kurang tertarik dengam model pembelajaran yang menggunakan buku cetak yang disediakan oleh sekolah. Selain itu, guru matapelajaran terkait juga menyatakan bahwa alat pembelajaran yang tersedia berjumlah terbatas. Penelitian dan pengembangan ini menggunakan model ADDIE. Observasi dan wawancara digunakan untuk mengumpulkan data awal penelitian. Sampel subjek uji coba penelitian ini adalah siswa kelas X SMK Negeri 1 Udanawu Blitar. Pengumpulan data penelitian dilakukan dengan menggunakan kuisioner dan lembar observasi. Berdasarkan hasil uji coba lapangan, penelitian dan pengembangan ini menghasilkan sebuah produk berupa bahan ajar digital perakitan komputer bermuatan augmented reality (AR) yang dinyatakan sangat layak digunakan sebagai bahan ajar dan dapat digunakan dalam proses pembelajaran untuk menumbuhkan keaktifan belajar dengan skor persentase mencapai $86,3 \%$.
\end{abstract}

\section{Kata Kunci}

bahan ajar, augmented reality, keaktifan belajar, siswa, sekolah kejuruan

TEKNO Vol. 29 Issue 1, p97-115 | Jurusan Teknik Elektro, Universitas Negeri Malang, Indonesia | September 2019

B. Afifah, T. Widiyaningtyas, U. Pujianto | Pengembangan bahan ajar perakitan komputer bermuatan augmented reality... 


\section{TEKNO Jurnal Teknologi Elektro dan Kejuruan}

http://journal2.um.ac.id/index.php/tekno | ISSN 1693-8739 / 2686-4657

\section{Pendahuluan}

Bahan ajar merupakan salah satu perangkat pembelajaran yang penting, baik bagi guru untuk mempersiapkan proses pembelajaran, maupun bagi peserta didik untuk mencapai kompetensi yang diharapkan (Indrawini dkk, 2017). Bahan ajar merupakan salah satu sumber belajar dalam bentuk konsep, prinsip, definisi, gugus isi atau konteks, data ataupun fakta, proses, nilai, kemampuan, keterampilan yang dirancang dan dikembangkan untuk memcapai tujuan pembelajaran sesuai dengan kebutuhan yang harus dicapai oleh siswa. Dalam proses pembuatan bahan ajar dapat memanfaatkan teknologi yang sangat berkembang saat ini, seperti teknologi terbarukan yaitu penggunaan teknologi augmented reality (AR) (Wahyudi dkk, 2017).

Salah satu mata pelajaran yang memiliki peranan penting dalam kompetensi keahlian Teknik Komputer dan Jaringan (TKJ) adalah mata pelajaran perakitan komputer. Mata pelajaran perakitan komputer bertujuan agar siswa mampu mengenal, memahami, dan mempraktekan ilmu untuk merakit komputer. Pada mata pelajaran perakitan komputer kelas $X$ TKJ, terdapat materi tentang perangkat proses, media penyimpanan dan tata letak komponen komputer.

Berdasarkan hasil observasi dan wawancara dengan beberapa siswa kelas X TKJ di SMK Negeri 1 Udanawu Blitar, terungkap bahwa peserta didik mengalami kesulitan dalam memahami materi salah satu materi perangkat proses, sehingga menyebabkan siswa merasa kurang tertarik dan kurang aktif belajar. Bahan dan alat ajar yang digunakan adalah buku cetak dan media papan tulis yang ditambah dengan metode ceramah. Penggunaan bahan ajar tersebut dinilai belum cukup untuk menjelaskan dan mengilustrasikan materi tentang perangkat proses, media penyimpanan, dan tata letak komputer. Hal tersebut didukung dengan tidak beraninya siswa untuk mencoba mengeksplorasi perangkat-perangkat komputer pada saat praktikum.

Berdasarkan kegiatan pembelajaran tersebut, siswa menjadi kurang aktif dan hanya mendengarkan materi-materi yang disampaikan oleh guru pengajar. Untuk menumbuhkan keaktifan, rasa ingin tahu, dan memperjelas dalam memahami materi perakitan komputer perlu adanya dukungan teknologi visualisasi (Suryani, 2017) yang bisa diterapkan dalam proses pembelajaran materi perangkat proses, media penyimpanan, dan tata letak komponen komputer.

Salah satu solusi pada permasalahan tersebut adalah pemanfaatan teknologi yang bisa memunculkan rasa ketertarikan peserta didik untuk mevisualkan perangkat proses, media penyimpanan dan tata letak komputer yaitu teknologi AR (Mustaqim, 2017; Setiawan dan Nugraha, 2018; Elmunsyah dkk, 2019). AR adalah sebuah teknologi yang menggabungkan beda maya dua dimensi ataupun tiga dimensi ke dalam sebuah lingkungan nyata lalu memproyeksikan benda-benda maya tersebut secara realitas dalam waktu nyata. AR merupakan teknologi terbaru yang memungkinkan penggunanya untuk memvisualkan dunia maya sebagai dari dunia nyata yang ada di sekitar secara efektif sehingga membuat dunia

TEKNO Vol. 29 Issue 1, p97-115 | Jurusan Teknik Elektro, Universitas Negeri Malang, Indonesia | September 2019

B. Afifah, T. Widiyaningtyas, U. Pujianto | Pengembangan bahan ajar perakitan komputer bermuatan augmented reality... 


\section{TEKNO Jumal Teknologi Eektro dan Kejuruon}

http://journal2.um.ac.id/index.php/tekno | ISSN 1693-8739 / 2686-4657

nyata seakan-akan terhubung dengan dunia maya yang dapat terjadi interaksi dari keduanya (Grier dkk, 2012).

Berdasarkan hal tersebut, pengembangan aplikasi pembelajaran bermuatan AR layak untuk dilakukan. Pengembangan aplikasi ini berbasis android dengan bantuan augmented reallity. Aplikasi ini akan dibuat menggunakan Unity dan Blender untuk membuat model dari pheripheral perangkat keras komputer yang berupa 2D maupun 3D serta Vuforia untuk melacak marker. Selain itu dalam aplikasi ini akan memanfaatkan kamera smartphone android untuk mendeteksi model 2D maupun 3D yang dijadikan sebagai marker.

Teknologi AR berbantuan smartphone dapat digunakan sebagai salah satu altenatif bahan ajar yang dapat digunakan oleh guru (Hakim, 2018; Hamzah dan Kurniadi, 2019). Manfaat dari bahan ajar berbasis mobile AR antara lain pengguna dapat mengoperasikan aplikasi ini kapanpun dan dimanapun secara mandiri (Amirullah, 2017) sehingga bisa menyesuaikan dengan kecepatan belajar masing-masing siswa, terdapat interaksi yang disesuaikan dengan kebutuhan pengguna, terdapat gambar atau video yang bisa dilihat sesuai sisi yang diambil sehingga dapat menimbulkan daya tarik bagi siswa serta memberikan gambaran nyata perangkat proses dan berbagai pheripheral perangkat keras komputer. Diharapkan aplikasi ini dapat dijadikan bahan awal untuk mata pelajaran perakitan komputer yang dapat memicu ketertarikan peserta didik dalam proses belajar.

\section{Metode}

Pengembangan bahan pembelajaran ini dilakukan berdasarkan model pengembangan ADDIE. Hal ini dikarenakan model pengembangan ADDIE memiliki tahapan yang sederhana, ringkas dan jelas. Selain itu waktu yang diperlukan untuk melakukan penelitian relative singkat, sehingga model ini mempermudah pengembang dalam melakukan penelitian. Oleh karena itu model pengembangan ini sesuai untuk pengembangan bahan ajar menggunakan teknologi AR adalah model pengembangan ADDIE.

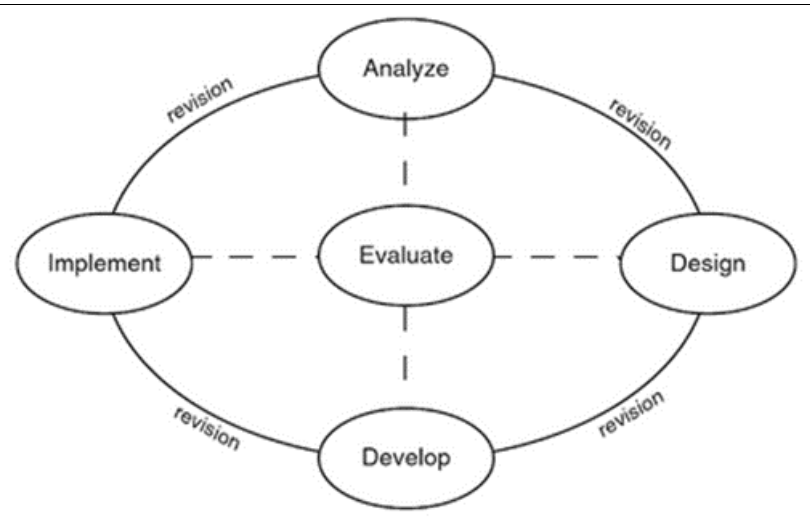

Gambar 1. Tahapan Model ADDIE

TEKNO Vol. 29 Issue 1, p97-115 | Jurusan Teknik Elektro, Universitas Negeri Malang, Indonesia | September 2019 B. Afifah, T. Widiyaningtyas, U. Pujianto | Pengembangan bahan ajar perakitan komputer bermuatan augmented reality... 


\section{TEKNO Jurnal Teknologi Elektro dan Kejuruan}

http://journal2.um.ac.id/index.php/tekno | ISSN 1693-8739 / 2686-4657

Model pengembangan ADDIE (Analysis-Design-Develop-Implementation-Evaluate). Tahapan penelitian dan pengembangan ADDIE menurut Branch (2009) terdiri dari lima fase, yaitu analyze (analisis), design (desain), develop (pengembangan), implement (implementasi), dan evaluate (evaluasi). Model penelitian dan pengembangan ADDIE dalam penerapan bahan ajar yang bermuatan AR ini dipilih karena pengembangannya lebih berorientasi pada sistem.

a) Tahap analyze.

Pada tahap ini, dilakukan identifikasi kebutuhan dan identifikasi masalah yang ada di lapangan untuk mendapatkan solusi dari permasalahan tersebut. Tahap ini dilakukan di SMK Negeri 1 Udanawu Blitar dengan menggunakan teknik wawancara langsung kepada guru pengapuh mata pelajaran perakitan komputer dan siswa kelas $\mathrm{X}$ program keahlian Teknik Komputer dan Jaringan (TKJ). Berikut ini merupakan tabel instrumen wawancara terhadap guru pengapuh mata pelajaran perakitan komputer dan siswa kelas X TKJ di SMK Negeri 1 Udanawu Blitar.

Tabel 1. Kisi-kisi instrumen wawancara guru pengampu matapelajaran

\begin{tabular}{cl}
\hline No & \\
\hline 1 & Bagaimana proses pembelajaran yang telah dilakukan selama ini? \\
2 & Bahan ajar apa aja yang digunakan untuk menunjang proses pembelajaran? dan seperti apa bentuknya? \\
3 & Bagaimana tanggapan siswa tentang mata pelajaran perakitan komputer? \\
4 & $\begin{array}{l}\text { Apakah siswa aktif betanya maupun memberikan tanggapan dalam dalam pembelajaran perakitan } \\
\text { komputer? }\end{array}$ \\
5 & $\begin{array}{l}\text { Masalah apa yang sering dihadapi siswa dalam proses pembelajaran perakitan komputer? } \\
6\end{array}$ \\
& $\begin{array}{l}\text { Apabila dikembangkan bahan ajar pembelajaran seperti apa yang dapat membantu untuk menyampaikan } \\
\text { materi mata pelajaran perakitan komputer, dan fitur apa saja yang bapak inginkan untuk dapat membantu }\end{array}$ \\
\hline
\end{tabular}

Tabel 2. Kisi-kisi instrumen wawancara siswa

\begin{tabular}{cl}
\hline No & \\
\hline 1 & Bagaimana proses pembelajaran yang telah dilakukan selama ini? \\
2 & Bahan ajar apa aja yang digunakan untuk menunjang proses pembelajaran? dan seperti apa bentuknya? \\
3 & Apa tanggapan anda (siswa) tentang mata pelajaran perakitan komputer? \\
4 & Apakah anda (siswa) aktif betanya maupun memberikan tanggapan dalam dalam pembelajaran perakitan \\
& komputer? \\
5 & Masalah apa yang sering anda (siswa) dihadapi dalam proses pembelajaran perakitan komputer? \\
\hline
\end{tabular}

Wawancara dengan guru menghasilkan pernyataan bahwa proses pembelajaran yang dilakukan selama ini menggunakan metode ceramah, media papan tulis dan buku cetak serta siswa aktif mendengarkan materi-materi yang diajarkan. Siswa lebih aktif mendengarkan dibandingkan dengan yang lain, contohnya untuk keaktifan motoriknya

TEKNO Vol. 29 Issue 1, p97-115 | Jurusan Teknik Elektro, Universitas Negeri Malang, Indonesia | September 2019 B. Afifah, T. Widiyaningtyas, U. Pujianto | Pengembangan bahan ajar perakitan komputer bermuatan augmented reality... 


\section{TEKNO Jumal Teknologi Eektro dan Kejuruon}

http://journal2.um.ac.id/index.php/tekno | ISSN 1693-8739 / 2686-4657

siswa kurang seperti ketika melakukan praktikum identifikasi komputer mereka kurang berani untuk maju kedepan kelas dan mengeksplorasi identifikasi komputer tersebut. Joko nugroho menyatakan, jika ingin melakukan pengembangan aplikasi maka yang dapat memudahkan siswa dalam belajar.

Wawancara dengan siswa kelas X TKJ 1 di SMK Negeri 1 Udanawu Blitar menghasilkan pernyataan bahwa proses pembelajarannya ceramah dan pemberian tugas-tugas, ketika mengerjakan tugas yang diberikan oleh guru mereka lebih suka searching di internet daripada membaca di modul yang di sediakan di sekolah. Serta peralatan yang disediakan dari pihak sekolah kurang memadai untuk melakukan praktikum perakitan komputer, dari pihak sekolah menyediakan alat praktikum 2 komputer untuk 1 kelas yang terdiri 35-36 siswa perkelasnya. Selain itu terdapat peserta didik yang menyatakan jika ada beberapa gambar tata letak komponen komputer di buku berbeda dengan komponen asli ketika praktikum yang menyebabkan kesulitan dalam mengenali tata letak komponen tersebut.

b) Tahap design.

Pada tahap desain berkaitan dengan sistem aplikasi yang ingin dibuat yang sudah disesuaikan dengan kebutuhan dari tahap sebelumnya. Berikut seperti yang ditunjukkan pada Gambar 2, merupakan alur dari penelitian dan pengembangan bahan ajar digital perakitan komputer bermuatan AR untuk menumbuhkan keaktifan belajar siswa kelas X TKJ di SMK Negeri 1 Udanawu Blitar.

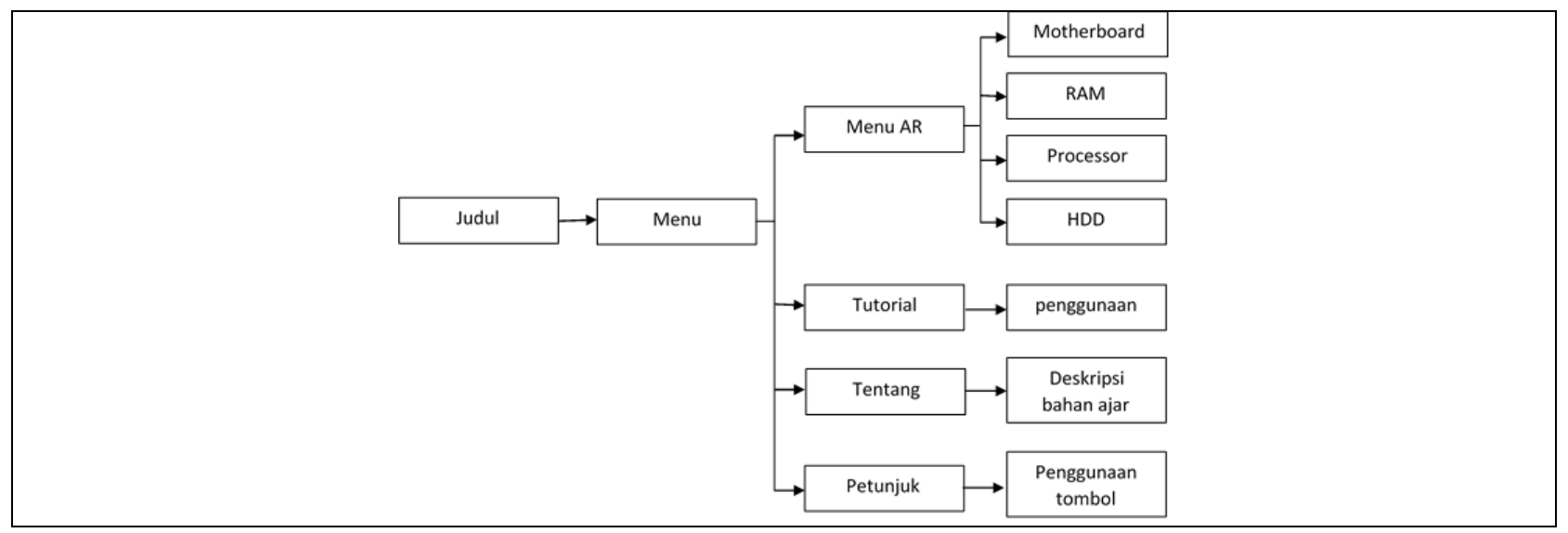

Gambar 2. Alur Bahan Ajar Bermuatan $A R$

c) Tahap develop

Pada tahap ini dilakukan pengembangan bahan ajar bermuatan AR dengan rancangan yang telah disusun pada tahap desain. Pengembangannya menggunakan Unity dan untuk pembuatan objek 2D maupun 3D menggunakan photoshop dan blender. Dalam pengembangan aplikasinya akan dilengkapi dengan tombol rotasi untuk dapat melihat objek

TEKNO Vol. 29 Issue 1, p97-115 | Jurusan Teknik Elektro, Universitas Negeri Malang, Indonesia | September 2019 B. Afifah, T. Widiyaningtyas, U. Pujianto | Pengembangan bahan ajar perakitan komputer bermuatan augmented reality... 


\section{TEKNO Jurnal Teknologi Elektro dan Kejuruan}

http://journal2.um.ac.id/index.php/tekno | ISSN 1693-8739 / 2686-4657

dari semua sisi. Materi bahan ajar perakitan komputer akan disusu sesuai dengan kurikulum 2013. Pada proses pengembangan akan dibantu dengan ahli media, kemudian di review pengembangan aplikasinya oleh tim ahli dan diuji coba kepada responden pengguna aplikasi yang bertujuan untuk mengetahui kekurangan dari aplikasi ini dan untuk mendapatkan kritik dan saran yang berguna untuk membangun bahan ajar perakitan komputer dengan bermuatan AR sehingga bahan ajar ini layak untuk dilakukan implementasi kepada target pengguna aplikasi ini.

d) Tahap implement.

Pada tahapan ini semua yang telah dilakukan pada tahapan analisis, desain dan pengembangan akan implementsikan dalam bentuk bahan ajar dan aplikasi AR yang berbentuk (.apk) yang kemudian dilanjutkan untuk dimaanfaatkan sebagai bahan ajar pendukung guru untuk proses pembelajaran mata pelajaran perakitan komputer untuk kelas $X$ TKJ di SMK Negeri 1 Udanawu yang bertujuan untuk meningkatkan keaktifan belajar siswa.

e) Tahap evaluate.

Pada tahapan ini dilakukan proses evaluasi terhadap bahan ajar AR yang telah dikembangkan. Hal ini merupakan tahapan untuk melihat apakah produk bahan ajar ini sudah sesuai dengan tujuan pembuatan produk atau belum. Evaluasi terhadap bahan ajar ini menggunakan angket yang berisi beberapa pertanyaan yang ditunjukan kepada ahli media, ahli materi dan siswa untuk memenuhi kebutuhan revisi. Revisi bertujuan untuk memperbaiki dan menyempurnakan bahan ajar AR jika terdapat kesalahan maupun kekurangan sehingga dapat memenuhi kriteria produk yang diharapakan.

Uji coba produk dalam penelitian ini dilakukan untuk mengumpulkan data yang digunakan sebagai dasar dalam menetapkan kelayakan produk yang dikembangkan. Dalam bagian ini hal yang harus diperhatikan adalah: (1) desain uji coba, (2) subjek uji coba, (3) jenis data, (4) instrumen pengumpulan data, dan (5) teknik analisis data.

1) Desain Uji Coba

Pada desain uji coba produk ini dibagi menjadi beberapa tahap yang meliputi:

a) Validasi ahli media dan ahli materi

Tahap validasi dilakukan untuk mengetahui kelayakan bahan ajar yang dikembangkan serta untuk mengetahui saran dan pendapat berkaitan dengan bahan ajar dan materi yang dikembangkan. Validasi ahli media dan ahli materi dilakukan oleh validator yaitu ahli media dan materi yang ahli dan menguasai bidang bahan ajar, materi pembelajaran maupun sistem yang sedang dikembangkan.

TEKNO Vol. 29 Issue 1, p97-115 | Jurusan Teknik Elektro, Universitas Negeri Malang, Indonesia | September 2019

B. Afifah, T. Widiyaningtyas, U. Pujianto | Pengembangan bahan ajar perakitan komputer bermuatan augmented reality... 


\section{TEKNO Jurnal Teknologi Elektro dan Kejuruan}

http://journal2.um.ac.id/index.php/tekno | ISSN 1693-8739 / 2686-4657

b) Uji coba kelompok kecil

Uji coba kelompok kecil dilakukan untuk mengetahui apakah bahan ajar yang dikembangkan layak digunakan dalam proses pembelajaran dan untuk mengetahui pendapat responden dalam skala kecil tentang bahan ajar yang dikembangkan. Uji coba kelompok kecil dilakukan dengan mengambil sampel sebanyak 10 siswa kelas $\mathrm{X}$ TKJ di SMK Negeri 1 Udanawu Blitar. Sepuluh siswa ini terdiri dari tiga siswa peringkat atas, empat siswa peringkat sedang, dan tiga siswa peringkat bawah. Pemilihan sepuluh siswa ini didasarkan pada pendapat yang menyatakan bahwa uji coba media dapat dilakukan kepada sepuluh siswa sebagai perwakilan populasi target.

c) Uji coba kelompok besar

Uji coba kelompok besar bertujuan untuk mengetahui apakah bahan ajar ini layak digunakan serta untuk mengetahui pendapat responden terhadap bahan ajar yang dikembangkan. Uji coba dilakukan dengan mengambil sampel sebanyak 30 siswa kelas $X$ TKJ di SMK Negeri 1 Udanawu Blitar. Pengambilan jumlah sampel minimal 30 peserta didik dengan berbagai karakteristik disesuaikan dengan karakteristik populasi sasaran.

2) Subjek Uji Coba

Subjek pada penelitian ini yaitu dosen sebagai ahli media dan ahli materi, satu guru pengampuh dan sepuluh siswa kelas X TKJ SMKN 1 Udanawu Blitar. Sepuluh siswa ini terdiri dari tiga siswa peringkat atas, empat siswa peringkat sedang, dan tiga siswa peringkat bawah.

3) Jenis Data

Pada penilitian dan pengembangan bahan ajar digital perakitan komputer bermuatan AR menggunakan jenis data yang didapat merupakan data kualitatif dan kuantitatif. Data kuantitatif diperoleh dari penilaian kelayakan bahan ajar berbasis AR oleh ahli media dan ahli materi yang berupa angket dengan skor 1 sampai 4 pada angket, sedangkan data kualitatif diperoleh dari hasil wawancara yang dilakukan pengembangan kepada informan dan validator.

4) Instrumen Pengumpulan Data Instrumen pengumpulan data berupa wawancara, observasi, dan angket. Wawancara dan observasi dilakukan untuk poses analisis kebutuhan. Sedangkan angket dilakukan untuk menguji kevalidan dan kepraktisan. Selain itu terdapat latihan soal untuk menguji keaktifan. Instrumen pengumpulan data angket untuk menguji kevalidan bahan ajar menggunakan skala likert. Skala likert merupakan jenis skala yang digunakan untuk mengukur variabel penelitian. Variabel penelitian ini kemudian dijabarkan menjadi indikator variabel kemudian

TEKNO Vol. 29 Issue 1, p97-115 | Jurusan Teknik Elektro, Universitas Negeri Malang, Indonesia | September 2019 B. Afifah, T. Widiyaningtyas, U. Pujianto | Pengembangan bahan ajar perakitan komputer bermuatan augmented reality... 


\section{TEKNO Jumal Teknologi Eektro dan Kejuruan}

http://journal2.um.ac.id/index.php/tekno | ISSN 1693-8739 / 2686-4657

dijadikan titik tolak penyusunan item-item instrumen, bisa berbentuk pertanyaan atau pernyataan.

Instrumen penelitian yang menggunakan skala likert dapat dibuat dalam bentuk multiple choice atau checklist. Jabawan angket menggunakan skala pengukuran skala likert, yakni dengan skor jawaban-jawaban: a) Nilai 4 berarti, sangat baik/sangat layak/senang sekali; b) Nilai 3 berarti, baik/ layak/senang; c) Nilai 2 berarti, cukup baik/cukup layak/ cukup senang; dan d) Nilai 1 yang berarti, kurang baik/kurang layak/kurang senang.

5) Teknik Analisis Data

a) Teknik analisis data uji validitas

Teknik analisis data yang digunakan yaitu analisis kuantitatif untuk mengetahui kelayakan dari media yang dikembangkan. Perhitungan diperoleh dari skor angket penilaian oleh ahli media dan ahli materi dengan menggunakan rumus perhitungan yang diadaptasi dari uraian Akbar (2013), dengan perhitungan rumus untuk mengolah data tunggal per butir pertanyaan (Pers. 1) dan Rumus untuk mengolah data secara keseluruhan (Pers. 2) sebagai berikut:

$V=\frac{T s e}{T s h} \times 100 \%$

Pers. 1

Keterangan:

- V : validitas berdasarkan presentase

- Tse : total skor (total skor yang dicapai)

- Tsh : jumlah skor maksimal

$V=\frac{\sum T s e}{\sum T s h} \times 100 \%$

Pers. 2

Keterangan:

- V : validitas berdasarkan presentase

- $\quad$ TTse : jumlah total skor (total skor yang dicapai)

- $\quad \sum$ Tsh : jumlah total skor maksimal

Data skor yang diperoleh dari hasil pengujian, dihitung persentasenya menggunakan rumus persentase seperti di atas. Setelah didapatkan hasil persentase dari perhitungan, kemudian data dikonversi ke dalam pernyataan predikat dan ditetapkan berdasarkan Tabel 3.

Tabel 3. Kriteria kualifikasi penilaian mengukur tingkat validitas

\begin{tabular}{lll}
\hline No & Persentase & Kategori \\
\hline
\end{tabular}

TEKNO Vol. 29 Issue 1, p97-115 | Jurusan Teknik Elektro, Universitas Negeri Malang, Indonesia | September 2019

B. Afifah, T. Widiyaningtyas, U. Pujianto | Pengembangan bahan ajar perakitan komputer bermuatan augmented reality... 


\section{TEKNO Jurnal Teknologi Elektro dan Kejuruan}

http://journal2.um.ac.id/index.php/tekno | ISSN 1693-8739 / 2686-4657

\begin{tabular}{cccc}
\hline 1 & $1-50$ & Tidak Valid & Revisi Total \\
2 & $51-70$ & Kurang Valid & Revisi Besar \\
3 & $71-85$ & Valid & Revisi Kecil \\
4 & $86-100$ & Sangat Valid & Tidak Revisi \\
\hline
\end{tabular}

Berdasarkan kriteria kualifikasi penilaian validitas yang telah dipaparkan, maka pengembangan bahan ajar digital perakitan komputer bermuatan AR untuk menumbuhkan keaktifan belajar pada siswa kelas X TKJ di SMK Negeri 1 Udanawu Blitar ini bisa dikatakan valid jika mencapai skor minimal $71 \%$.

b) Teknik analisis data uji keaktifan

Teknik analisis data untuk data uji keaktifan adalah dengan menggunakan lembar observasi. Aspek yang diukur pada keaktifan siswa yaitu: (1) aspek emotional: siswa berani menyampaikan pendapat di depan kelas, (2) listening: siswa mendengarkan pada saat guru menjelaskan materi dan penggunaan bahan ajar AR, (3) mental: siswa aktif bekerja sama memecahkan masalah, (4) oral: siswa mengajukan pertanyaan atau tanggapan saat proses pembelajaran berlangsung, (5) visual: siswa memperhatikan penjelasan dari guru tentang penggunaan bahan ajar AR, (6) writing: siswa mengerjakan tugas yang ada pada bahan ajar AR, dan (7) metric: siswa aktif dalam praktikum dan mengeksplorasi bahan ajar AR. Pada lembar observasi ini adalah menggunakan persentase keaktifan setiap siswa. Perhitungan persentase data keaktifan siswa dalam proses pembelajaran dihitung menggunakan rumus sebagai berikut:

Keaktifan $=\frac{\sum \text { skor seluruh peserta didik }}{\sum \text { skor maksimal }} \times 100$

Pers. 3

Skor hasil pengujian dihitung persentasenya menggunakan rumus persentase seperti di atas. Setelah didapatkan hasil persentase dari perhitungan, kemudian data dikonversi ke dalam pernyataan predikat berdasarkan kriteria pada Tabel 3.

\section{Hasil}

Pengembangan yang dihasilkan adalah Bahan Ajar Digital Perakitan Komputer Bermuatan AR. Bahan Ajar Digital Perakitan Komputer Bermuatan AR berupa aplikasi mobile dengan ekstensi .apk. Bahan ajar ini dikembangkan dengan menggunakan teknologi AR yang dapat di aplikasi kan kedalam smartphone android. Pengembangan aplikasi ini menggunakan model pengembangan ADDIE yang telah dijelaskan pada metode. Hasil dari pengembangan bahan ajar digital perakitan komputer bermuatan AR akan dijelaskan sebagai berikut:

1) Cover Judul

TEKNO Vol. 29 Issue 1, p97-115 | Jurusan Teknik Elektro, Universitas Negeri Malang, Indonesia | September 2019

B. Afifah, T. Widiyaningtyas, U. Pujianto | Pengembangan bahan ajar perakitan komputer bermuatan augmented reality... 


\section{TEKNO Jumal Teknologi Eektro dan Kejuruon}

http://journal2.um.ac.id/index.php/tekno | ISSN 1693-8739 / 2686-4657

Cover merupakan tampilan awal dari sebuah buku maupun modul. Cover ini menampilkan informasi awal tentang nama bahan ajar, nama mata pelajaran, materi, tahun pembuatan bahan ajar, semester, kelas, nama pembuat dan logo bahan ajar seperti yang ditampilkan pada Gambar 2.

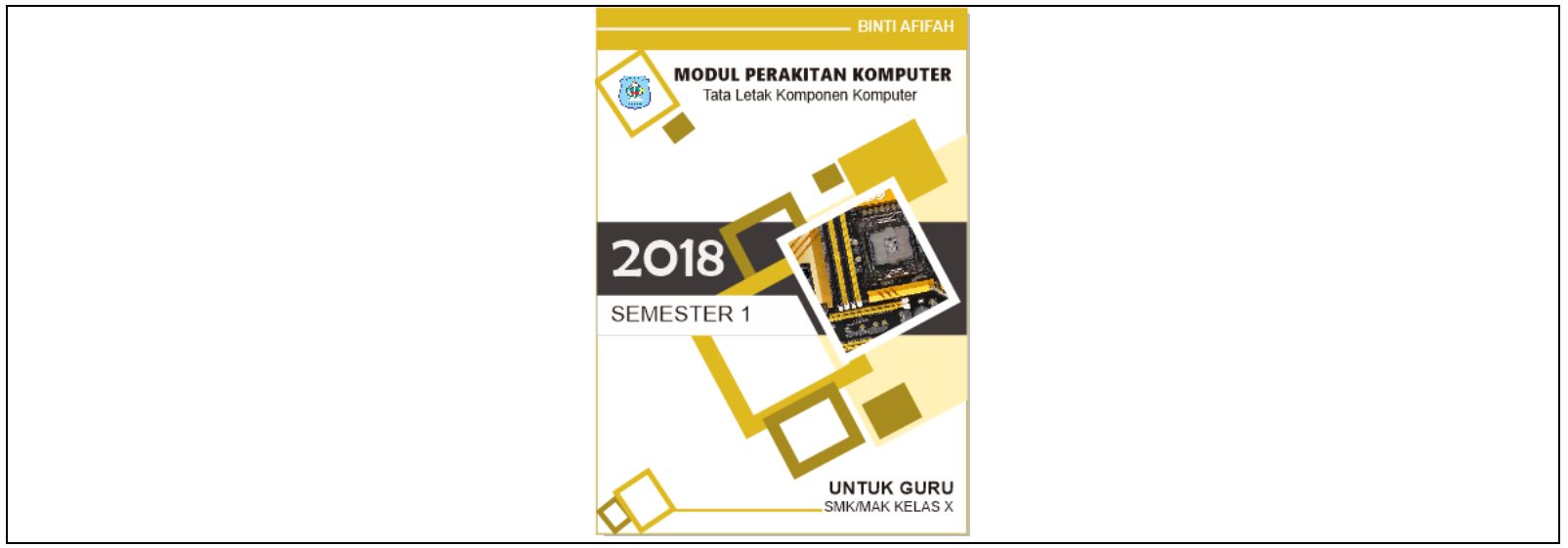

Gambar 2. Tampilan Cover Modul

2) Tujuan Pembelajaran

Pada bagian tujuan pembelajaran, pengembang memperoleh tujuan berdasarkan silabus kurikulum 2013 kelas X Jurusan Teknik Komputer dan Jaringan dengan rincian sebagai berikut:

a) Tata letak komponen komputer

- Memahami tentang cara merakit komputer

- Memahami tentang motherboard

- Mengamati komponen-komponen motherboard dan tata letak komponen pada motherboard

- Menjelaskan komponen-komponen motherboard dan tata letak komponen pada motherboard

b) Perangkat proses

- Menjelaskan tentang perangkat proses

- Menjelaskan komponen-komponen perangkat proses

- Menjelaskan komponen-komponen perangkat pendingin

c) Media penyimpanan

- Memahami komponen media penyimpanan

- Menganalisis komponen media penyimpanan

- Menjelaskan komponen-komponen media penyimpanan

TEKNO Vol. 29 Issue 1, p97-115 | Jurusan Teknik Elektro, Universitas Negeri Malang, Indonesia | September 2019

B. Afifah, T. Widiyaningtyas, U. Pujianto | Pengembangan bahan ajar perakitan komputer bermuatan augmented reality... 


\section{TEKNO Junnal Teknologi Elekro dan Kejuruan}

http://journal2.um.ac.id/index.php/tekno | ISSN 1693-8739 / 2686-4657

berikut merupakan tampilan dari tujuan pembelajaran seperti pada Gambar 3.

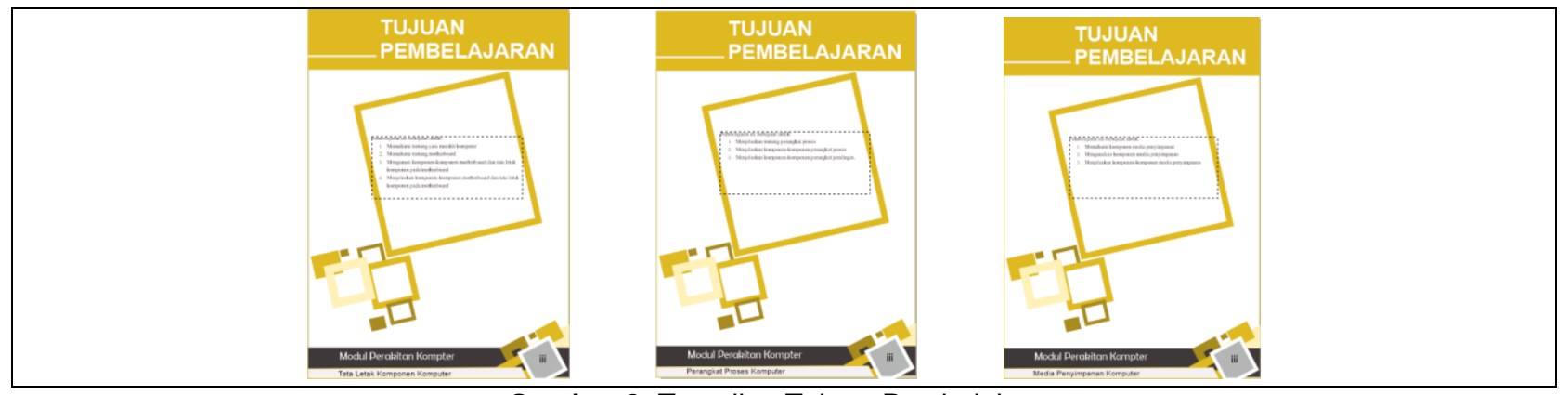

Gambar 3. Tampilan Tujuan Pembelajaran

3) Halaman Judul

Halaman judul merupakan halaman yang memberikan informasi kepada pembaca mengenai tahun pembelajaran modul dibuat, judul modul dan nama penyusun modul. Halaman judul ditunjukan pada Gambar 4.

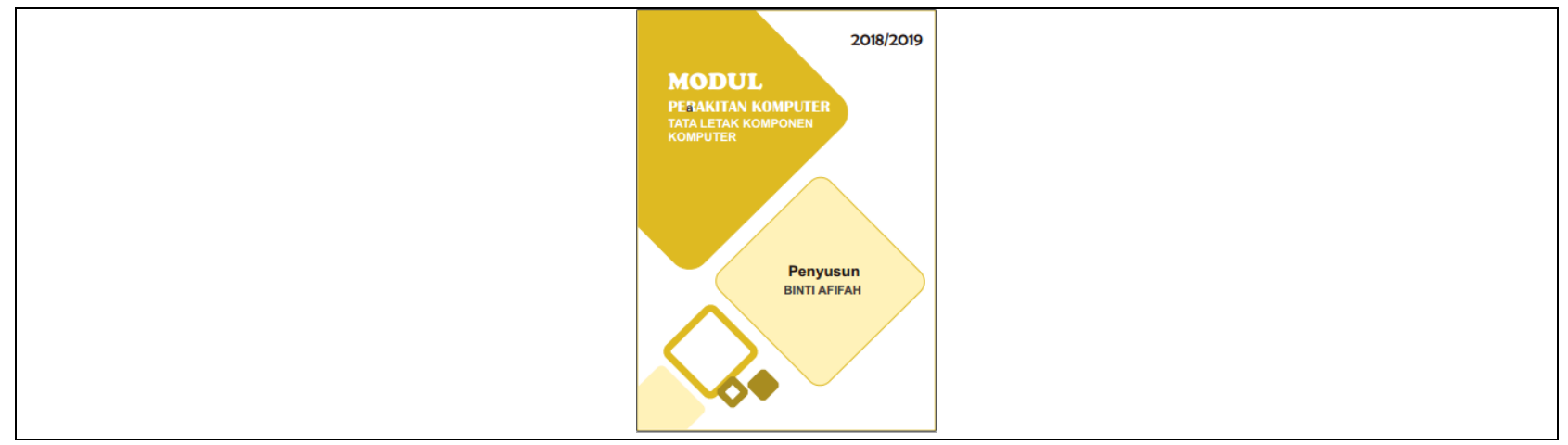

Gambar 4. Tampilan Halaman Judul

4) Kata Pengantar

Halaman kata pengantar merupakan paparan dari ucapan terima kasih penyusun kepada pihak-pihak yang terlibat dalam penyusunan bahan ajar. Pada halaman ini juga diuraikan cangkupan materi yang dibahas dalam modul dan harapan penyusun dari penggunaan modul ini dalam proses pembelajaran. Halaman kata pengantar ditunjukan pada Gambar 5 . 


\section{TEKNO Jumal Teknologi Eekrto dan Kejuruan}

http://journal2.um.ac.id/index.php/tekno | ISSN 1693-8739 / 2686-4657

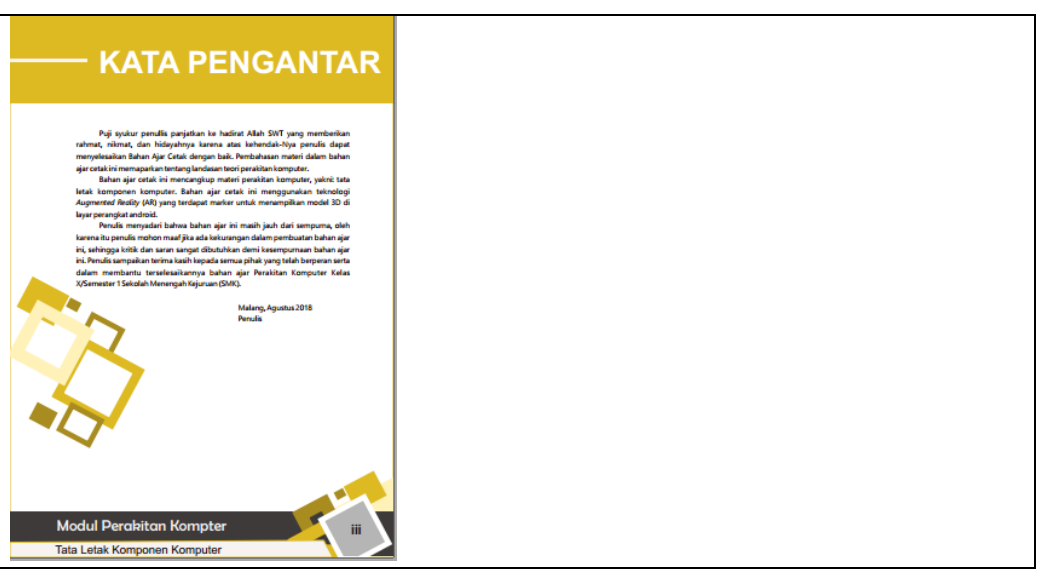

Gambar 5. Tampilan Halaman Kata Pengantar

5) Tampilan Awal Aplikasi

Tampilan awal aplikasi merupakan tampilan yang muncul pertama kali ketika memulai mengakses bahan ajar digital perakitan komputer bermuatan augmented reality. Tampilan awal aplikasi berisi nama aplikasi dan main menu yang terdiri dari scan AR, bantuan, pengembang dan menu keluar. Tampilan awal aplikasi seperti pada Gambar 6.

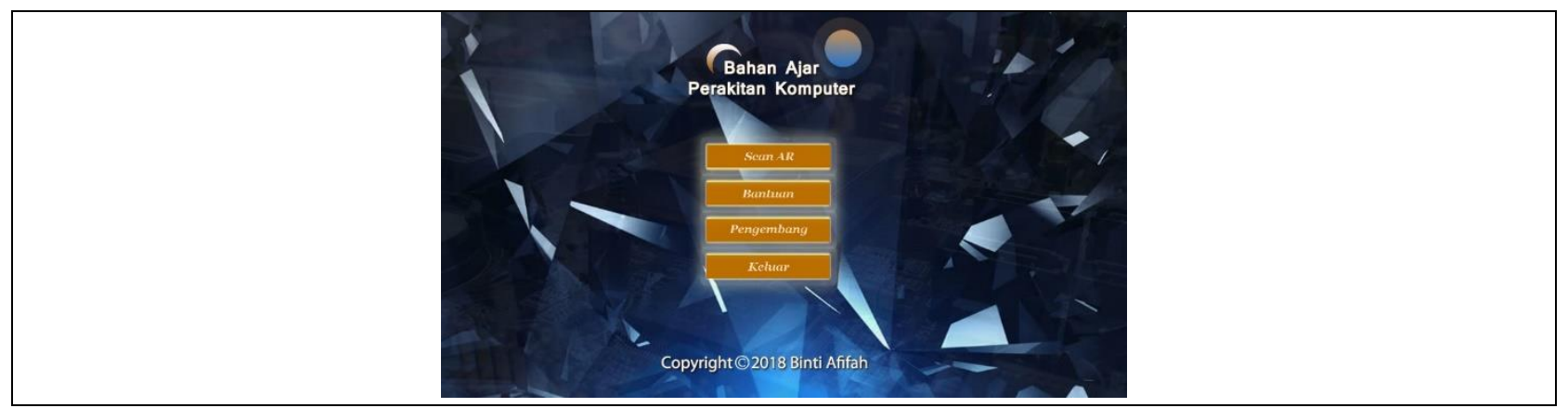

Gambar 6. Tampilan Awal Aplikasi

\section{6) Menu Scan AR}

Ketika menekan button Scan, maka pengguna akan masuk ke dalam teknologi AR, di dalam menu Scan AR berisi tombol back dan scan kamera yang berfungsi untuk scanning marker AR. Dalam proses scanning marker akan menampilkan video maupun objek 3D. Berikut tampilan dari menu Scan AR seperti pada Gambar 7. 


\section{TEKNO Junal Teknologi Elekrio dan Kejuruan}

http://journal2.um.ac.id/index.php/tekno | ISSN 1693-8739 / 2686-4657

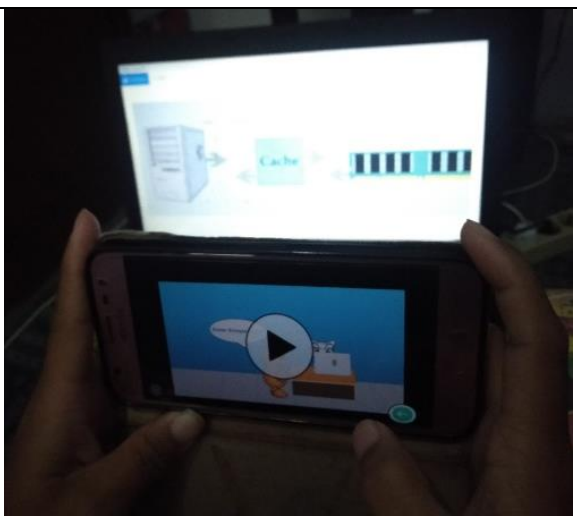

Gambar 7. Menu Scan AR

7) Menu Bantuan

Menu bantuan berisi tentang informasi penggunaan aplikasi seperti penggunaan dari menu Scan AR, penggunaan dari marker, fungsi tombol play, fungsi tombol back, dan fungsi dari menu keluar. Berikut tampilan dari menu bantuan seperti pada Gambar 8.

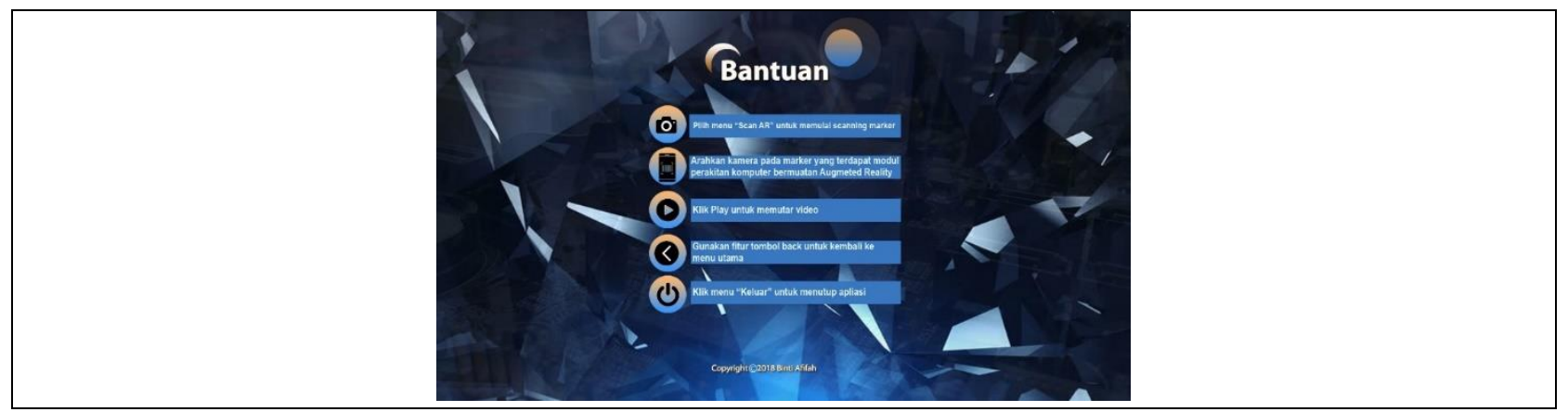

Gambar 8. Tampilan Menu Bantuan

8) Menu Pengembang

Menu pengembang berisi tentang identitas pengembang aplikasi bahan ajar digital perakitan komputer bermuatan augmented reality. Berikut tampilan menu pengembang seperti pada Gambar 9. 


\section{TEKNO Jurnal Teknologi Elektro dan Kejuruan}

http://journal2.um.ac.id/index.php/tekno | ISSN 1693-8739 / 2686-4657

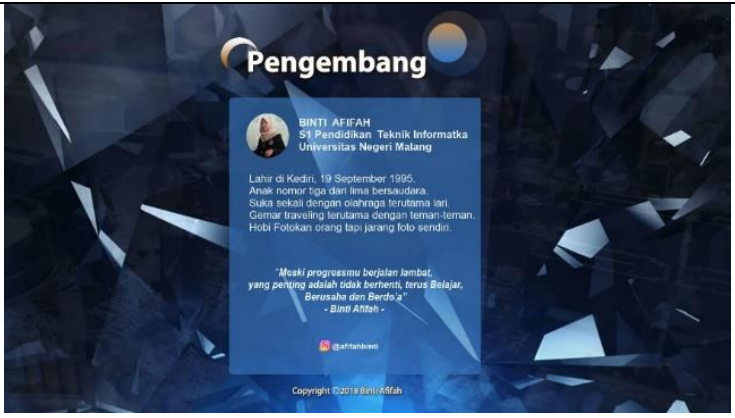

Gambar 9. Tampilan Menu Pengembang

9) Menu Keluar

Menu keluar merupakan menu yang digunakan untuk pengguna keluar dari aplikasi bahan ajar digital perakitan komputer bermuatan AR.

Uji validasi materi dilakukan oleh seorang ahli yang memiliki kemampuan dan pengetahuan terhadap mata pelajaran Perakitan Komputer. Uji validasi dilakukan oleh guru Kompetensi Keahlian Teknik Komputer dan Jaringan di SMKN 1 Udanawu Blitar. Data hasil validasi ahli materi dapat dilihat pada Tabel 4.

Tabel 4. Data hasil validasi ahli materi

\begin{tabular}{|c|c|c|c|c|c|}
\hline \multirow{2}{*}{ No } & \multirow{2}{*}{ Aspek Penilaian } & \multicolumn{2}{|c|}{ Penilaian } & \multirow{2}{*}{ V (\%) } & \multirow{2}{*}{ Kriteria } \\
\hline & & $T_{\text {se }}$ & $T_{\text {sh }}$ & & \\
\hline 1 & Aspek Pendahuluan & 16 & 16 & 100 & sangat valid \\
\hline 2 & Aspek Pembelajaran & 16 & 16 & 100 & sangat valid \\
\hline 3 & Aspek Isi & 16 & 16 & 100 & sangat valid \\
\hline 4 & Aspek Tugas & 16 & 16 & 100 & sangat valid \\
\hline \multirow[t]{4}{*}{5} & Aspek Rangkuman & 16 & 16 & 100 & sangat valid \\
\hline & $\sum \mathbf{T}_{\mathrm{se}}$ & 80 & & & \\
\hline & $\sum T_{s h}$ & 80 & & & \\
\hline & Rata-rata (V) & 80 & & & sangat valid \\
\hline
\end{tabular}

Berdasarkan data dari validasi materi oleh ahli, didapatkan validitas dalam persentase yang ditampilkan pada Tabel 4 dengan rata-rata 100\%, dengan aspek pendahuluan yaitu 100,0\%, aspek pembelajaran yaitu 100\%, aspek isi yaitu 100\%, aspek tugas yaitu $100 \%$, dan aspek rangkuman 100\%. Berikut adalah bagan hasil validasi ahli materi seperti pada Gambar 10. 


\section{TEKNO Jumal Teknologi Eektro dan Kejuruan}

http://journal2.um.ac.id/index.php/tekno | ISSN 1693-8739 / 2686-4657

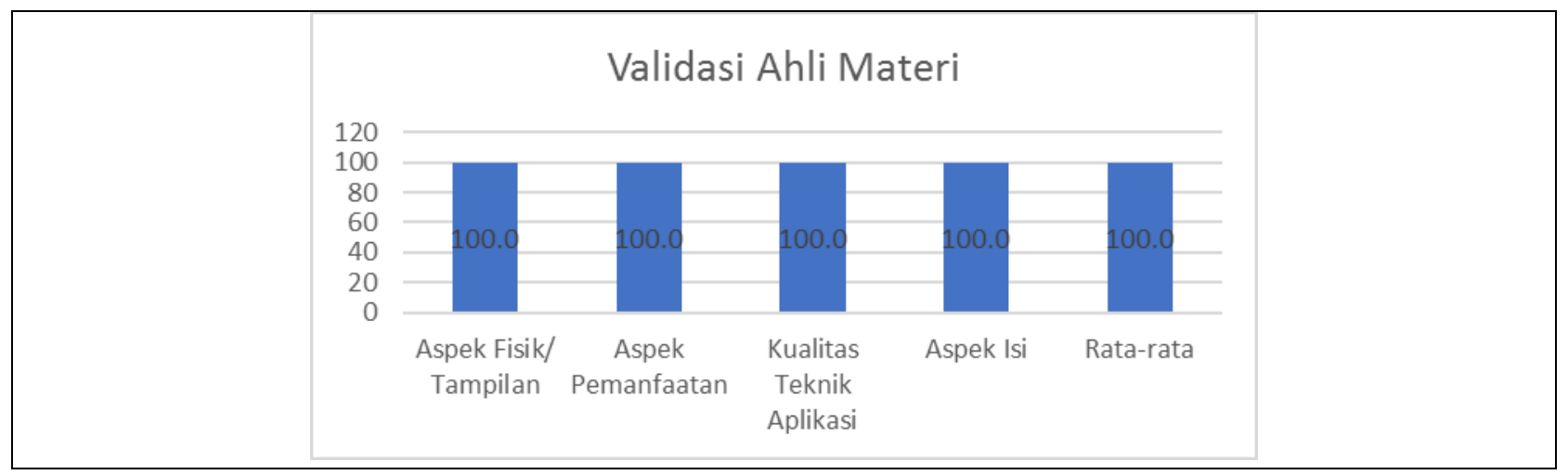

Gambar 10. Hasil Validasi Ahli Materi

Validasi media dilaksanakan oleh dosen Teknik Elektro di Universitas Negeri Malang yang berkeahlian dalam pengembangan media pembelajaran. Validasi ini dilakukan dengan menggunakan angket instrumen penilaian ahli media. Data yang dihimpun berupa data kuantitatif pada aspek fisik atau tampilan, aspek pendahuluan, aspek pemanfaatan, dan aspek kualitas teknis aplikasi dengan jumlah pertanyaan 29 soal. Berikut adalah data hasil validasi media disajikan pada Tabel 5.

Tabel 5. Data hasil validasi ahli media

\begin{tabular}{|c|c|c|c|c|c|}
\hline \multirow{2}{*}{ No } & \multirow{2}{*}{ Aspek Penilaian } & \multicolumn{2}{|c|}{ Penilaian } & \multirow{2}{*}{ V (\%) } & \multirow{2}{*}{ Kriteria } \\
\hline & & $\mathbf{T}_{\text {se }}$ & $\mathbf{T}_{\text {sh }}$ & & \\
\hline 1 & Aspek Fisik atau Tampilan & 34 & 36 & 100 & sangat valid \\
\hline 2 & Aspek Pedahuluan & 16 & 16 & 93,8 & sangat valid \\
\hline 3 & Aspek Pemanfaatan & 24 & 24 & 100 & sangat valid \\
\hline \multirow[t]{4}{*}{4} & Aspek Kualitas Teknik Aplikasi & 38 & 40 & 97,5 & sangat valid \\
\hline & $\sum \mathrm{T}_{\mathrm{se}}$ & 114 & & & \\
\hline & $\sum T_{\text {sh }}$ & 116 & & & \\
\hline & Rata-rata (V) & 98,3 & & & sangat valid \\
\hline
\end{tabular}

Berdasarkan data hasil validasi media oleh ahli, didapatkan validitas dalam persentase yang ditampilkan pada Tabel 5 dengan hasil rata-rata 98,3\%, dengan aspek fisik atau tampilan yaitu $100 \%$, aspek pendahuluan yaitu 93,8\%, aspek pemanfaatan yaitu 100\%, dan aspek kualitas Teknik aplikasi 97,5\%. Berikut adalah bagan hasil validasi ahli media seperti pada Gambar 11. 


\section{TEKNO Jumal Teknologi Eektro dan Kejuruan}

http://journal2.um.ac.id/index.php/tekno | ISSN 1693-8739 / 2686-4657

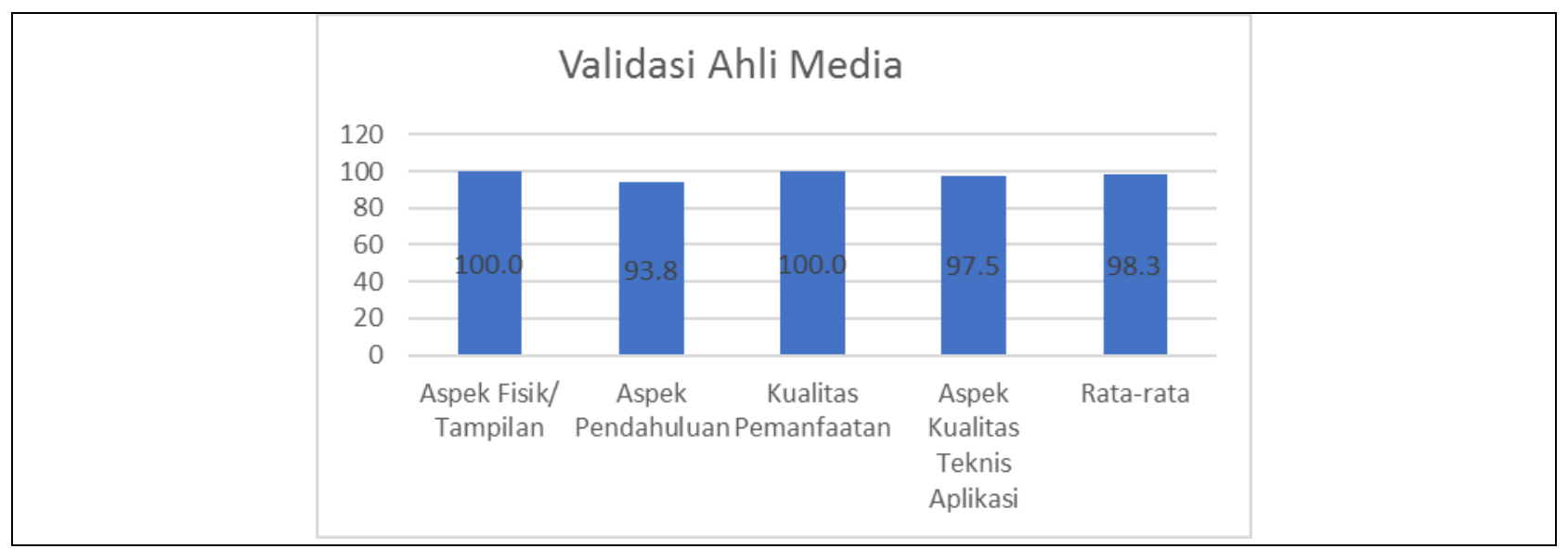

Gambar 11. Hasil Validasi Ahli Media

Uji coba kelompok kecil dilakukan oleh 15 orang peserta didik yang diambil dikelas X TKJ 2 . Uji coba dilaksanakan menggunakan angket uji coba responden yag terlampir. Data yang dihimpun berupa data kuantitatif pada aspek fisik atau tampilan, aspek pemanfaatan, kualitas teknis aplikasi dan aspek isi dengan jumlah pertanyaan sebanyak 20 soal. Berikut data hasil uji coba kelompok kecil disajikan pada Tabel 6.

Tabel 6. Data hasil uji coba kelompok kecil

\begin{tabular}{|c|c|c|c|c|c|}
\hline \multirow{2}{*}{ No } & \multirow{2}{*}{ Aspek Penilaian } & \multicolumn{2}{|c|}{ Penilaian } & \multirow{2}{*}{$\begin{array}{c}\text { V } \\
(\%)\end{array}$} & \multirow{2}{*}{ Kriteria } \\
\hline & & $T_{\text {se }}$ & $\mathbf{T}_{\text {sh }}$ & & \\
\hline 1 & Aspek Fisik atau Tampilan & 216 & 240 & 90,0 & Sangat Valid \\
\hline 2 & Aspek Pemanfaatan & 275 & 300 & 91,7 & Sangat Valid \\
\hline 3 & Aspek Kualitas Teknik Aplikasi & 310 & 360 & 86,1 & Sangat Valid \\
\hline \multirow[t]{4}{*}{4} & Aspek Isi & 270 & 300 & 90,0 & Sangat Valid \\
\hline & $\sum T_{\text {se }}$ & 1071 & & & \\
\hline & $\sum T_{s h}$ & 1200 & & & \\
\hline & Rata-rata (V) & 89,3 & & & sangat valid \\
\hline
\end{tabular}

Berdasarkan data hasil uji coba kelompok kecil, didapatkan validitas dalam persentase yang ditampilkan pada Tabel 6 dengan nilai rata-rata 89,3\%, dengan aspek fisik atau tampilan yakni $90 \%$, aspek pemanfaatan yaitu $91,7 \%$, aspek kualitas teknis aplikasi yaitu $86,1 \%$ dan aspek isi yaitu $90 \%$. Berikut adalah bagan hasil uji coba kelompok kecil seperti pada Gambar 12. 


\section{TEKNO Jumal Teknologi Eektro dan Kejuruan}

http://journal2.um.ac.id/index.php/tekno | ISSN 1693-8739 / 2686-4657

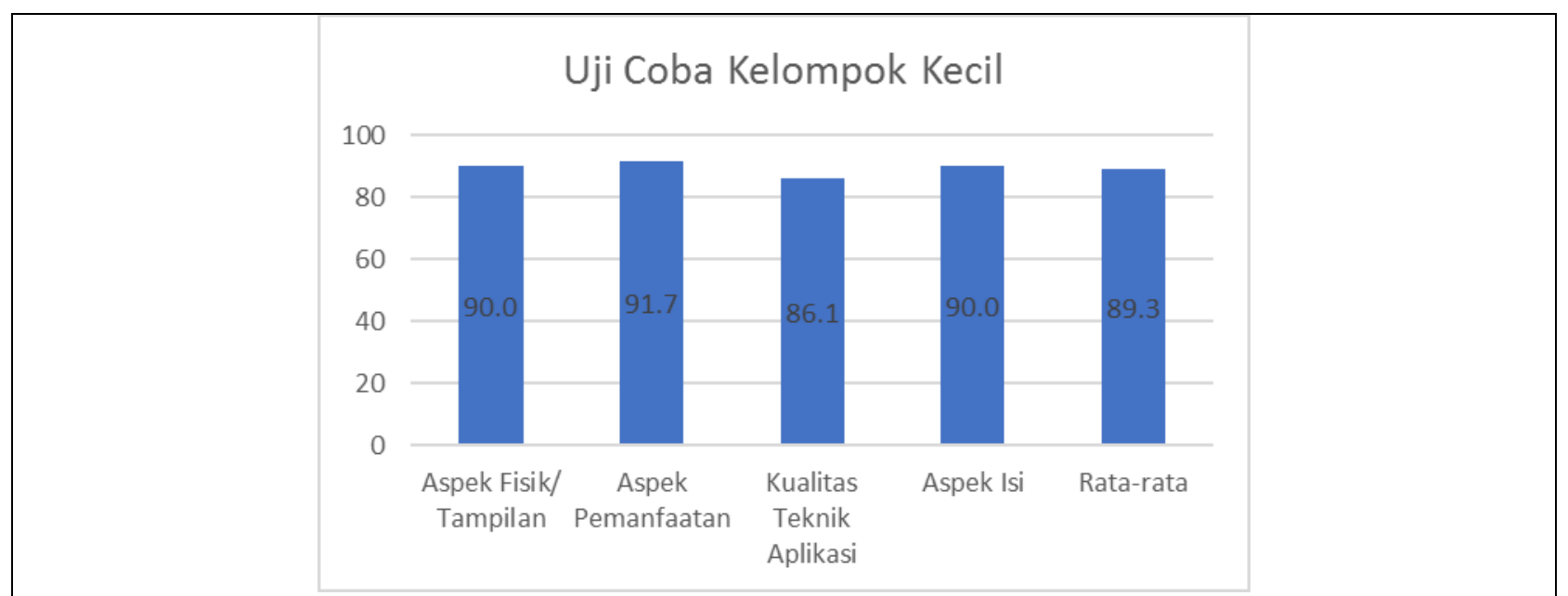

Gambar 12. Hasil Uji Coba Kelompok Kecil

Uji coba kelompok besar atau uji coba lapangan dilakukan oleh 35 orang peserta didik yang diambil di kelas $X$ TKJ 2. Uji coba dilaksanakan menggunakan angket uji coba peserta didik yang terlampir. Data yang dihimpun berupa data kuantitatif pada aspek fisik atau tampilan, aspek pemanfaatan, kualitas teknis aplikasi dan aspek isi dengan jumlah pertanyaan sebanyak 20 soal. Berikut data hasil uji coba kelompok besar atau uji coba lapangan disajikan pada Tabel 7.

Tabel 7. Data hasil uji coba kelompok besar

\begin{tabular}{|c|c|c|c|c|c|}
\hline \multirow{2}{*}{ No } & \multirow{2}{*}{ Aspek Penilaian } & \multicolumn{2}{|c|}{ Penilaian } & \multirow{2}{*}{$\begin{array}{c}V \\
(\%)\end{array}$} & \multirow{2}{*}{ Kriteria } \\
\hline & & $T_{\text {se }}$ & $\mathbf{T}_{\text {sh }}$ & & \\
\hline 1 & Aspek Fisik atau Tampilan & 508 & 560 & 90,7 & Sangat Valid \\
\hline 2 & Aspek Pemanfaatan & 628 & 700 & 89,7 & Sangat Valid \\
\hline 3 & Aspek Kualitas Teknik Aplikasi & 695 & 840 & 82,7 & Valid \\
\hline \multirow[t]{4}{*}{4} & Aspek Isi & 623 & 700 & 89,0 & Sangat Valid \\
\hline & $\sum \mathrm{T}_{\mathrm{se}}$ & 2454 & & & \\
\hline & $\sum \mathrm{T}_{\text {sh }}$ & 2800 & & & \\
\hline & Rata-rata (V) & 87,6 & & & Sangat Valid \\
\hline
\end{tabular}

Berdasarkan data hasil uji coba kelompok besar, didapatkan validitas dalam persentase yang ditampilkan pada Tabel 7 dengan nilai rata-rata 87,6\%, dengan aspek fisik atau tampilan yakni $90,7 \%$, aspek pemanfaatan yaitu $89,7 \%$, aspek kualitas teknis aplikasi yaitu $82,7 \%$ dan aspek isi yaitu $89 \%$. Berikut adalah bagan hasil uji coba kelompok besar seperti pada Gambar 13. 


\section{TEKNO Junal Teknologi Eektro don Kejuruan}

http://journal2.um.ac.id/index.php/tekno | ISSN 1693-8739 / 2686-4657

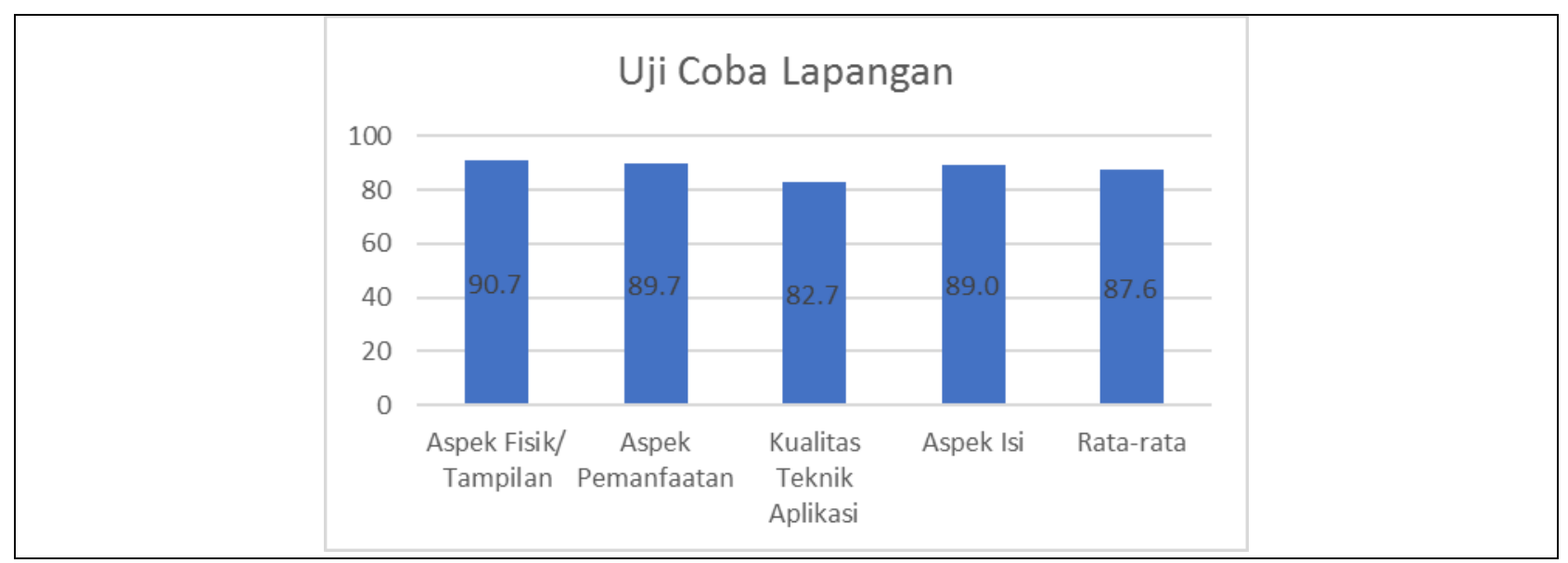

Gambar 12. Hasil Uji Coba Kelompok Besar

\section{Kesimpulan}

Produk yang dihasilkan dalam penelitian dan pengembangan ini adalah bahan ajar digital perakitann komputer bermuatan augmented reality untuk siswa kelas $X$ TKJ di SMKN 1 Udanawu Blitar. Bahan ajar perakitan komputer ini berisi tiga materi pembelajaran yang meliputi: (1) tata letak komponen komputer; (2) perangkat proses; dan (3) media penyimpanan. Bahan ajar digital perakitan komputer bermuatan augmented reality ini digunakan pada smartphone android dengan spesifikasi minimal 4.0 atau Jelly Bean dengan RAM $1 \mathrm{~GB}$. Bahan ajar digital perakitan komputer bermuatan augmented reality telah diuji melalui empat tahapan pengujian yaitu: tahap validasi oleh ahli materi, tahapan validasi oleh ahli media, uji coba kelompok kecil dan uji coba kelompok besar dengan hasil sangat layak digunakan sebagai bahan ajar mata pelajaran perakitan komputer.

Pengujian bahan ajar digital perakitan komputer bermuatan augmented reality dilakukan melalui empat tahapan yaitu: (1) tahap validitas materi dari guru di SMKN 1 Udanawu Blitar diperoleh persentase sebesar 100,0 \%; (2) validitas media oleh guru di SMKN 1 Udanawu Blitar diperoleh persentase sebesar 96,6 \%; (3) uji coba kelompok kecil yang dilakukan oleh 15 orang peserta didik kelas X TKJ 2 di SMKN 1 Udanawu Blitar diperoleh persentase sebesar 89,3\%; dan (4) uji coba kelompok besar atau uji coba lapangan yang dilakukan oleh 35 orang peserta didik kelas X TKJ 2 di SMKN 1 Udanawu Blitar diperoleh persentase sebesar 87,6 \%. Dari hasil yang didapatkan jadi dapat disimpulkan bahwa bahan ajar digital perakitan komputer bermuatan augmented reality dinyatakan sangat layak digunakan sebagai bahan ajar dan dapat digunakan dalam proses pembelajaran untuk menumbuhkan keaktifan belajar mencapai $86,3 \%$. 


\section{TEKNO Jumal Teknologi Elektro dan Kejurvon}

http://journal2.um.ac.id/index.php/tekno | ISSN 1693-8739 / 2686-4657

\section{Daftar Rujukan}

Amirullah, G. dan Hardinata, R. 2017. Pengembangan Mobile Learning bagi Pembelajaran. Jurnal Kesejahteraan Keluarga dan Pendidikan, 4, 2, 97-101.

Elmunsyah, H., Hidayat, W. N., dan Asfani, K. 2019. Interactive learning media innovation: utilization of augmented reality and pop-up book to improve user's learning autonomy. Journal of Physics: Conference Series, 1193, 1, 1-6.

Grier, R. A., Thiruvengada, H., Ellis, S. R., Havig, P. Hale, K. S., dan Hollands, J. G. 2012. Augmented Reality - Implications toward Virtual Reality, Human Perception and Performance. Proceedings of the Human Factors and Ergonomics Society Annual Meeting, $56,1,1351-1355$.

Hakim, L. 2018. Lentera Pendidikan, 20, 1, 59-72.

Hamzah, S. dan Kurniadi, D. 2019. Voteknika, 7, 3, 146-157.

Indrawini, T., Amirudin, A., dan Widiati, U. 2016. Pentingnya Pengembangan Bahan Ajar Tematik untuk Mencapai Pembelajaran Bermakna bagi Siswa Sekolah Dasar. Prosiding Seminar Nasional Mahasiswa Kerjasama Direktorat Jenderal Guru dan Tenaga Kependidikan Kemendikbud 2016, 2, 1-7.

Mustaqim, I. 2017. Jurnal Edukasi Elektro, 1, 1, 36-48.

Setiawan, A. B. dan Nugraha, A. C. 2018. Jurnal Pendidikan Teknik Elektro, 8, 5, 354-361.

Suryani, N. 2016. Pengembangan Media Pembelajaran Sejarah berbasis IT. Jurnal Sejarah dan Budaya, 10, 2, 186-196.

Wahyudi, U. M. W., Wibawanto, H., dan Hardyanto, W. 2017. Innovative Journal of Curriculum and Educational Technology, 6, 2, 98-107. 